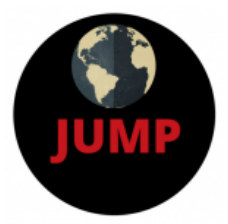

ISSN: 2574-3465 Print/ ISSN: 2574-3481 Online

Volume 3, Issue 1 (2019), pp. 94-96

(C) Journal of Underrepresented and Minority Progress

http://ojed.org/jump

doi: 10.32674/jump.v3i1.576

\title{
Experiencing the African Diaspora in My Travels Abroad
}

\author{
Marcellas Preston \\ Morgan State University, USA
}

"Travel makes one modest. You see what a tiny place you occupy in the world."

— Gustav Flaubert

I am a habitual traveler: I have been to 11 different countries since December 2016. Traveling has become a part of my life-it comes to the point where if I do not travel for 2 months, I get moody. Traveling exposes me to the world and different cultures and standards. Traveling also exposes me to the African Diaspora around the world. I enjoy eating different food around the world. My wife laughs at me because I make sure I eat some sort of "street food" that is native to the country city or neighborhood I'm in. When I visit a new country, I want to become a part of that country while I'm there. So I embrace the culture and everything it has to offer.

I cannot trace my heritage or where I'm from originally; however, as a "Black" man, I feel a connection with all members of the diaspora. I first felt this during my visit to Cuba. I was elated to see so many Black faces like mine and they were so welcoming. Being born and raised in Miami, I grew up around Cubans, but they had White faces and often would dislike me for the color of my skin. Being in Cuba and seeing the opposite let me know that the diaspora is real. Here I learned the real history of Fidel Castro and his relationship with the United States. Before visiting different countries, I research the country to find the diaspora there. The area is usually far from the tourist area, kept out of the public eye.

While in Ghana I visited a school in Nima, one of the poorest cities in Ghana. The kids at the school were full of life and energy. I was amazed that they spoke both English and French fluently. I saw some of the math work they were doing and was shocked at the high level of math they were 
doing. We spent the next day in the market and went to one of the restaurants after a day of buying and bartering with street vendors. In this restaurant, I ate rice grilled chicken and plantains. I realized that I had the same meal in Colombia and Cuba. Then it hit me that this is an original African dish, and when they were enslaved they brought it with them. The next day we went to El Mina, which is the castle that housed enslaved Africans before their departure. This was the highlight of my trip because I've always wanted to visit this place - a place where my ancestors realized that they would never see their homeland again. While there, I felt a presence in the air-it felt weird, and I experienced a lot of emotions. The whole time I was visualizing the past and how my ancestors went through this horror.

While visiting Cartagena, Colombia, I visited the small village of San Basilio de Palenque. This village was started by enslaved Africans who escaped slavery around 1604 . This place was filled with bright colors and smiling faces. They embraced their African roots even though most of them have never been to Africa. When I was there, they called me their brother and it felt like home. The food was amazingly seasoned as well. They also performed some of their music for the group I traveled with. I can understand most Spanish, but I could not understand them because they speak Spanish as well as a language that mixes Spanish and other African languages. However, the music had a beat that was very familiar, and we danced and had a great time. The beat told me that no matter where we are, our music gives the same feelings.

My most recent trip was to London and Paris. I've always wanted to visit Paris and the Eiffel Tower, so this was an amazing trip for me. While in London I visited Brixton, which is the neighborhood where most of the African Diaspora lives. It had great art all around, with people selling food and souvenirs. As soon as we got off the subway, we heard the drums and the music, and it felt like home. My next trip will be in Egypt where we will visit Cairo and Luxor. This trip I will finally get to see one of the eight wonders of the world in the pyramids of Giza. I'm interested in the camel riding and the beauties of Egypt.

In the research of Mary M. Dwyer, she finds several benefits to studying abroad including: "[a]chieving a greater understanding of one's own cultural values and biases, continuing to be influenced in one's interactions with people from different cultures, and developing a more sophisticated way of looking at the world...."

Although my travels have been independent study abroad trips, I find they have impacted my work and I have gained more cultural exposure 
and further understanding of shared values. My research is also informed by the lessons that I've learned in various countries that have given me a greater sense of world history. Lastly, traveling abroad has made me a better person overall, and I see the world differently. After visiting impoverished areas and hearing the stories of those who were impacted, I've often found that I cannot complain about some of the small issues I face here in America. I am patiently waiting for my next adventure.

\section{REFERENCES}

Dwyer M.M. (2004). More is better: The impact of study abroad program duration. Frontiers: The Interdisciplinary Journal of Study Abroad, 10(Fall 2004), 151-163. Retrieved from https://files.eric.ed.gov/fulltext/EJ891454.pdf 